\title{
Toxicity and Bioaccumulation Studies of Heavy Metals on a Freshwater Fish
}

\author{
Ezeonyejiaku $\mathrm{CD}^{1 *}$, Okoye $\mathrm{CO}^{2}$ and Ezenwelu $\mathrm{CO}^{3}$ \\ ${ }^{1}$ Department of Zoology, Nnamdi Azikiwe University Awka, Nigeria \\ ${ }^{2}$ Department of Zoology \& Environmental Biology, University of Nigeria Nsukka, \\ Nigeria \\ ${ }^{3}$ Department of Applied Biochemistry, Nnamdi Azikiwe University, Awka, Nigeria
}

*Corresponding author: Ezeonyejiaku Chigozie Damian, Department of Zoology, Nnamdi Azikiwe University Awka, Nigeria; Email: cd.ezeonyejiaku@unizik.edu.ng

\section{Research Article}

Volume 3 Issue 3

Received Date: July 07, 2019

Accepted Date: August 01, 2019

Published Date: August 07, 2019

DOI: $10.23880 /$ ijoac-16000169

\section{Abstract}

Heavy metals are stable and persistent environmental contaminants of aquatic environments. Toxicological survey was done to investigate the toxicity of selected hazardous heavy metals and also to determine the rates and levels of bioaccumulation attainable in Clarias gariepinus when exposed to single, binary and multiple mixtures of heavy metals in laboratory bioassays. There were significant departures when the toxicity levels of mixtures (binary and multiple) were compared to the toxicity levels of the individual metals when acting alone against the same test animal. When most of the mixtures were tested against the test Clarias gariepinus, the interaction between the constituents was mainly in conformity with the model of synergism while only a few cases conformed to the model of antagonism. Exposure of the test animal Clarias gariepinus to sublethal concentration of the metal mixtures under the joint action studies resulted in a reduction in the concentration of $\mathrm{Cd}, \mathrm{Pb}$, and $\mathrm{Cr}$ accumulated by the test organism, when compared to the concentrations accumulated by the animal during the single action studies. Therefore, Clarias gariepinus was found to bioaccumulate heavy metals ( $\mathrm{Cd}, \mathrm{Cr}$ and $\mathrm{Pb}$ ) to varying degrees, dependent on the type of metals, period of exposure, and concentration of metal compound in the test media and the joint action of the metals in the system.

Keywords: Heavy Metals; Toxicity, Clarias gariepinus; Bioaccumulation; Synergism; Antagonism

\section{Introduction}

Heavy metals are natural constituents of the marine and freshwater environment, generally found in very low concentrations. Generally, the expression' Heavy Metals' is used where there are connotations of toxicity. A number of authors have critically reviewed the usage of the term "Heavy Metals" and have called it hopelessly imprecise and objectionable [1]. Heavy metals are dangerous to aquatic organisms and it can be bioaccumulated in the food chain leading to diseases in human. They occur in the environment both as a result of natural processes and as pollutants from human activities. According to the literatures, heavy metal bioaccumulation 


\section{International Journal of Oceanography \& Aquaculture}

by fish and subsequent distribution in organs is greatly interspecific. In addition, many factors can influence metal uptake like sex, age, size, reproductive cycle, swimming pattern, feeding behavior, and geographical location [2]. For these reasons, evaluation of heavy metal levels in commercially important fish is important from a toxicological perspective, verifying their effects on the natural environment and significant health risk arising from fish consumption.

\section{Materials and Methods}

\section{Test Animals}

Fish samples (Clarias gariepinus) were collected for toxicological studies from a fish farm and transported in glass tank to the laboratory.

\section{Bioassay Studies}

After acclimatization, the fish samples were randomly assigned to bioassay containers. For the series of bioassays, 20 Clarias gariepinus were exposed per treatment in two replicates (10 fish per replicate). There was a control in all the treatments. In these bioassays after range finding preliminary trials, fish samples were exposed to series of concentrations of each heavy metal compounds.

A series of bioassays were carried out, but this time, the acclimatized animals were exposed to different concentrations of binary and multiple mixtures of heavy metal salts in pre-defined ratios. There was always 10 Clarias gariepnius per bioassay container exposed at each concentration or treatment. Each treatment was replicated 2 times, meaning that 20 Clarias gariepinus were exposed per concentration of heavy metal mixtures as specified below.

In all bioassays, mortality data were taken once every $24 \mathrm{~h}$ over the $96 \mathrm{~h}$ duration. Test animals were taken as dead if they failed to respond by moving away when touched gently with a glass rod.

\section{Bioaccumulation Studies}

Clarias gariepinus was exposed to sublethal concentration of single metal compounds $(\mathrm{Pb}, \mathrm{Cr}, \mathrm{Cd})$ in semi-static bioassays. In this series of experiments, Clarias gariepinus was exposed to only sub-lethal concentrations $\left(1 / 10^{\text {th }}\right.$ and $1 / 100^{\text {th }}$ of $\left.96-\mathrm{h} \mathrm{LC}_{50}\right)$ of the selected metal salts acting singly as specified below. A total of 60 test animals were exposed per sublethal concentration in 3 replicates (20 animals per replicate). In this series of bioassay that went on for 28 days in order to investigate the rate of bioaccumulation, the semi-static bioassay procedure was always adopted to avoid drastic changes in concentration of test media via evaporation and excessive reduction in dissolved oxygen level. In this semi-static procedure, each test medium was changed into a fresh solution at exactly the same concentration of heavy metal salt once every 7 days, transferring the same exposed test animals into the freshly prepared test media over the 28-day period of the experiment. At predetermined time intervals (day 0, 7, 14, 21 and 28), One live Clarias gariepinus per replicate, making three per treatment were randomly selected, cleaned thoroughly with distilled water and placed in labeled polythene bags in which they were kept frozen awaiting digestion of the extracted whole animal tissue and analysis for test metals by AAS [3].

Bioaccumulation of heavy metals by Clarias gariepinus was also exposed to sublethal concentrations of binary and multiple heavy metals compounds in mixtures.In order to evaluate the possible influence of ionic competition for uptake sites or other modes of possible interactions on rates and amount of bioaccumulation of metals by animals exposed to mixtures of metallic elements, the following series of bioassays were carried out in the laboratory. A similar semi-static bioassay as described above was carried out, but for this present bioassays, Clarias gariepinus was exposed to sublethal concentrations of binary mixtures of $\mathrm{Cd}-\mathrm{Pb}, \mathrm{Cd}-\mathrm{Cr}, \mathrm{Cr}-$ $\mathrm{Pb}$ and multiple mixtures of $\mathrm{Cd}-\mathrm{Cr}-\mathrm{Pb}$. The binary and multiple mixtures consisted of sublethal concentration of each constituent metal salt, the computation of which was based on pre-determined fractions $\left(1 / 10^{\text {th }}\right.$ and $\left.1 / 100^{\text {th }}\right)$ of the $96-\mathrm{h} \mathrm{LC}_{50}$ values of the test metals obtained in acute toxicity of joint action experiments conducted in this work.

\section{Statistical Analysis}

Toxicological data based on quantal response (mortality) was analysed by probit analysis, after Finney (1971). The probit analysis, dependent on maximum likelihood interactive regression was done by a computer programme designed and implemented by Ge le Patourel, imperial College London and adopted by Don-Pedro [4]. The above analysis when it involved mortality-dosage data resulted in derivation of $\mathrm{LC}_{50}, \mathrm{LC}_{95}$ and $\mathrm{LC}_{5}$ with their 95\% confidence limits and other relevant parameters, while when mortality time was analyzed, $\mathrm{Lc}_{50}$ values were obtained. Pooled cumulative quantal response (mortality) data (of replicates/treatment) was used in probit analysis following accepted toxicological procedures [4]. 


\section{International Journal of Oceanography \& Aquaculture}

TF (Toxicity Factor): This was used to measure the relative potency ratio.

$\mathrm{RPR}=\mathrm{LC}_{50}$ of a compound $\mathrm{X}$

$\mathrm{LC}_{50}$ of another compound $\mathrm{Y}$

Where $\mathrm{X}$ is the metal with higher value of $\mathrm{LC}_{50}$ and $\mathrm{Y}$ is the metal with the lowest value of $\mathrm{LC}_{50}$ Histograms were used to compare the $\mathrm{LC}_{50}$ values of the metals when acting singly.

\section{Analysis of Data and Measurement of Joint Action Toxicity of Binary and multiple Mixtures of Test Compounds}

Joint action toxicity was determined and analyzed using synergistic ratio model, according to Hewlett and Plackett (1969) as follows:

S.R (Synergistic ratio) $=\mathrm{LC}_{50}$ of a chemical acting alone $\mathrm{LC}_{50}$ of chemical + additive mixture

\section{Translation of Results}

Where S. R = 1 - describes additive action

S.R $=<1-$ describes antagonism

S.R $=>1-$ describes synergism

Significance /overlap in $95 \%$ confidence limit of the detected $96 \mathrm{hLC}_{50}$ values were determined using the ChiSquare technique. The limit of significance was 0.05 .

\section{Results}

\section{Single Acute Toxicity of Cadmium (Cd) Against Clarias gariepinus}

The 96-h $\mathrm{LC}_{50}$ values of Cadmium against Clarias gariepinus are shown in 1 . The values were calculated from $24 \mathrm{~h}-96 \mathrm{~h}$ of the study duration. There was no significant difference observed among the $96-\mathrm{h} \mathrm{LC}_{50}$ values of the fish species.

\begin{tabular}{|c|c|c|c|c|}
\hline Time & LC $_{\mathbf{5}}$ & LC $_{\mathbf{5 0}}$ & LC $_{\mathbf{9 5}}$ & Toxicity factor (TF) \\
\hline $24 \mathrm{~h}$ & 4.443 & 11.253 & 28.505 & 1.36 \\
\hline $48 \mathrm{~h}$ & 3.493 & 10.146 & 29.472 & 1.23 \\
\hline $72 \mathrm{~h}$ & 3.692 & 8.773 & 20.843 & 1.06 \\
\hline $96 \mathrm{~h}$ & 3.794 & 8.280 & 18.071 & 1.00 \\
\hline
\end{tabular}

Table 1: Acute toxicity of cadmium acting singly against Clarias gariepinus (mg/L).

Single Acute Toxicity of Lead (Pb) Against Clarias gariepinus

Table 2 presents the $24 \mathrm{~h}-96-\mathrm{hCC}_{50}$ values of lead against Clarias gariepinus. There were no observed significant variations $(\mathrm{P}>0.05)$ on the $24-\mathrm{h} \mathrm{LC}_{50}, 48-\mathrm{h} \mathrm{LC}_{50}$,

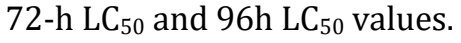

\begin{tabular}{|c|c|c|c|c|}
\hline Time & LC $_{\mathbf{5}}$ & $\mathbf{L C}_{\mathbf{5 0}}$ & LC $_{\mathbf{9 5}}$ & Toxicity factor (TF) \\
\hline $24 \mathrm{~h}$ & 38.732 & 94.545 & 230.788 & 1.35 \\
\hline $48 \mathrm{~h}$ & 28.745 & 84.285 & 247.140 & 1.20 \\
\hline $72 \mathrm{~h}$ & 28.941 & 73.714 & 187.757 & 1.05 \\
\hline $96 \mathrm{~h}$ & 29.540 & 70.183 & 166.745 & 1.00 \\
\hline
\end{tabular}

Table 2: Acute toxicity of Lead acting singly against Clarias gariepinus (mg/L).

\section{Single Acute Toxicity of Chromium (Cr) Against Clarias gariepinus}

The $96-\mathrm{hLC}_{50}$ values through $24 \mathrm{~h}$ duration of fish species exposure are shown on Table 3 . The $\mathrm{LC}_{50}$ values for the 24-96h exposure recorded no variation $(\mathrm{P}>0.05)$.

\begin{tabular}{|c|c|c|c|c|}
\hline Time & $\mathbf{L C}_{\mathbf{5}}$ & $\mathbf{L C}_{\mathbf{5 0}}$ & $\mathbf{L C}_{\mathbf{9 5}}$ & Toxicity factor (TF) \\
\hline $24 \mathrm{~h}$ & 36.394 & 99.577 & 272.450 & 1.57 \\
\hline $48 \mathrm{~h}$ & 21.257 & 90.995 & 389.517 & 1.43 \\
\hline $72 \mathrm{~h}$ & 26.888 & 75.077 & 209.631 & 1.81 \\
\hline $96 \mathrm{~h}$ & 19.986 & 63.546 & 202.049 & 1.00 \\
\hline
\end{tabular}

Table 3: Acute toxicity of Chromium acting singly against Clarias gariepinus (mg/L). 


\section{International Journal of Oceanography \& Aquaculture}

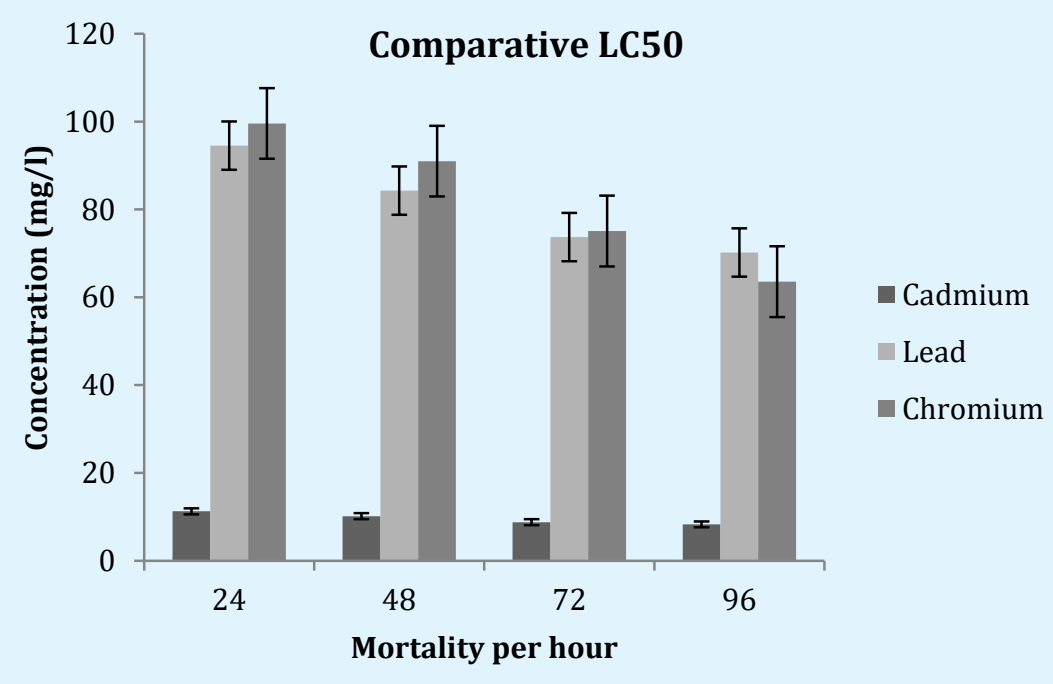

Figure 1: Comparative $\mathrm{LC}_{50}$ values of the singly acting different heavy metals against Clarias gariepinus.

The numerical comparative chart of the $\mathrm{LC}_{50}$ values of $\mathrm{Cr}, \mathrm{Pb}$ and $\mathrm{Cd}$ studied against the Clarias gariepinus is shown on Figure 1. From the figure above, cadmium (Cd) was the most toxic metal and lead $(\mathrm{Pb})$ the least toxic metal to the test animals based on $96-\mathrm{LC}_{50}$.

\section{Binary Acute Toxicity of Cadmium (Cd) and Lead (Pb) Against Clarias gariepinus}

The relative joint acute toxicity $\left(24 \mathrm{~h}-96-\mathrm{h} \mathrm{LC}_{50}\right.$ values) of the ratios of mixtures for cadmium and lead against the catfish are presented in Table 4.

\begin{tabular}{|c|c|c|c|c|}
\hline Time & LC $_{\mathbf{5}}$ & $\mathbf{L C}_{\mathbf{5 0}}$ & LC $_{\mathbf{9 5}}$ & Toxicity factor \\
\hline $24 \mathrm{~h}$ & 4.158 & 38.093 & 349.025 & 2.15 \\
\hline $48 \mathrm{~h}$ & 4.158 & 38.093 & 349.025 & 2.15 \\
\hline $72 \mathrm{~h}$ & 2.608 & 25.129 & 242.124 & 1.42 \\
\hline $96 \mathrm{~h}$ & 2.342 & 17.699 & 135.753 & 1.00 \\
\hline
\end{tabular}

Table 4: Acute toxicity of binary mixture of Cadmium $(\mathrm{Cd})$ and Lead $(\mathrm{Pb})$ against Clarias gariepinus $(\mathrm{mg} / \mathrm{L})$.

\section{Binary Acute Toxicity of Cadmium (Cd) and Chromium (Cr) against Clarias gariepinus}

The 24-h $\mathrm{LC}_{50}$, 48-h $\mathrm{LC}_{50}$, 72-h $\mathrm{LC}_{50}$ and 96-h $\mathrm{LC}_{50}$ values of binary combination of $\mathrm{Cd}$ and $\mathrm{Cr}$ in a specified ratio against Clarias gariepinus are shown on Table 5. The $24-96-\mathrm{h} \mathrm{LC}_{50}$ values were not significant $(\mathrm{P}>0.05)$, though mortality response increased with increase in exposure time and concentration of the test heavy metals.

\begin{tabular}{|c|c|c|c|c|}
\hline Time & LC $_{\mathbf{5}}$ & LC $_{\mathbf{5 0}}$ & LC $_{\mathbf{9 5}}$ & Toxicity factor \\
\hline $24 \mathrm{~h}$ & 66.633 & 105.213 & 166.130 & 1.71 \\
\hline $48 \mathrm{~h}$ & 54.993 & 84.516 & 129.888 & 1.38 \\
\hline $72 \mathrm{~h}$ & 46.286 & 71.424 & 110.214 & 1.16 \\
\hline $96 \mathrm{~h}$ & 44.134 & 61.444 & 85.542 & 1.00 \\
\hline
\end{tabular}

Table 5: Acute toxicity of binary mixture of $\mathrm{Cd}$ and $\mathrm{Cr}$ against Clarias gariepinus (mg/L). 


\section{International Journal of Oceanography \& Aquaculture}

Binary Acute Toxicity of Chromium (Cr) and Lead (Pb) against Clarias gariepinus

The $\mathrm{LC}_{50}$ values for the exposure duration of Clarias gaeripinus to the binary mixture of $\mathrm{Cr}$ and $\mathrm{Pb}$ are shown in Table 6. Only 24-h $\mathrm{LC}_{50}$ was seen to be significant $(\mathrm{P}<0.05)$ with the heterogeneity factor used in the confidence limit calculation of $95 \%$.

\begin{tabular}{|c|c|c|c|c|}
\hline Time & LC $_{5}$ & LC $_{\mathbf{5 0}}$ & LC $_{\mathbf{9 5}}$ & Toxicity factor \\
\hline $24 \mathrm{~h}$ & 17.074 & 54.646 & 174.904 & 2.08 \\
\hline $48 \mathrm{~h}$ & 12.115 & 35.012 & 101.185 & 1.33 \\
\hline $72 \mathrm{~h}$ & 12.023 & 32.172 & 86.088 & 1.22 \\
\hline $96 \mathrm{~h}$ & 9.042 & 26.263 & 76.284 & 1.00 \\
\hline
\end{tabular}

Table 6: Acute Toxicity of Binary Mixture of $\mathrm{Cr}$ and $\mathrm{Pb}$ against Clarias gariepinus (mg/L).

Joint Action Toxicity of Multiple Mixtures of Heavy Metal Compounds against Clarias gariepinus
The $\mathrm{LC}_{50}$ values of multiple mixtures of $\mathrm{Cd}, \mathrm{Pb}$ and $\mathrm{Cr}$ over 24- 96-h exposure duration are shown on Table 7. All the $\mathrm{LC}_{50}$ values were statistically significant $(\mathrm{P}<0.05)$ except value of $24 \mathrm{~h}$ duration $(\mathrm{P}>0.05)$ at $95 \%$ confidence limit.

\begin{tabular}{|c|c|c|c|c|}
\hline Time & LC $_{\mathbf{5}}$ & $\mathbf{L C}_{\mathbf{5 0}}$ & $\mathbf{L C}_{\mathbf{9 5}}$ & Toxicity factor \\
\hline $24 \mathrm{~h}$ & 32.537 & 70.893 & 154.465 & 3.97 \\
\hline $48 \mathrm{~h}$ & 6.584 & 50.294 & 384.165 & 2.81 \\
\hline $72 \mathrm{~h}$ & 6.003 & 31.828 & 168.739 & 1.78 \\
\hline $96 \mathrm{~h}$ & 2.356 & 17.878 & 135.658 & 1.00 \\
\hline
\end{tabular}

Table 7: Acute toxicity of multiple mixture of $\mathrm{Cd}: \mathrm{Pb}$ : $\mathrm{Cr}$ against Clarias gariepinus (mg/L).

Bioaccumulation of Heavy Metals (Cd, Pb And Cr) By Clarias gariepinus Exposed to Sublethal Concentrations of Each Metal in Single Action Laboratory Studies
The heavy metal concentrations of single accumulation of the metal by Clarias gariepinus are shown in Table 8. The concentrations were derived based on the $1 / 10^{\text {th }}$ and $1 / 100^{\text {th }}$, of their respective $96-\mathrm{h} \mathrm{LC}_{50}$ values.

\begin{tabular}{|c|c|c|c|c|c|c|}
\hline Days & \multicolumn{2}{|c|}{ Cd } & \multicolumn{2}{c|}{ Pb } & \multicolumn{2}{c|}{ Cr } \\
\hline & $1 / 10^{\text {th }}$ & $1 / 100^{\text {th }}$ & $1 / 10^{\text {th }}$ & $1 / 100^{\text {th }}$ & $1 / 10^{\text {th }}$ & $1 / 100^{\text {th }}$ \\
\hline 0 & $\mathrm{ND}$ & $\mathrm{ND}$ & $\mathrm{ND}$ & $\mathrm{ND}$ & $\mathrm{ND}$ & $\mathrm{ND}$ \\
\hline 7 & $2.216+0.001$ & $0.272+0.001$ & $0.118+0.001$ & $0.018+0.001$ & $89.630+0.001$ & $9.752+0.001$ \\
\hline 14 & $2.503+0.001$ & $0.311+0.001$ & $0.121+0.001$ & $0.021+0.001$ & $106.410+0.001$ & $10.281+0.001$ \\
\hline 21 & $2.904+0.001$ & $0.337+0.001$ & $0.125+0.001$ & $0.022+0.001$ & $113.920+0.001$ & $10.810+0.001$ \\
\hline 28 & $3.079+0.001$ & $0.351+0.001$ & $0.128+0.001$ & $0.022+0.001$ & $131.812+0.001$ & $12.544+0.001$ \\
\hline
\end{tabular}

Table 8: Bioaccumulation Concentrations of $\mathrm{Cd}, \mathrm{Pb}$ and $\mathrm{Cr}$ in Clarias gariepinus( $\mu \mathrm{g} / \mathrm{g})$.

From the above table, there was increasing concentration of the metals in fish with increase in exposure duration for both $1 / 10^{\text {th }}$ and $1 / 100^{\text {th }}$ respectively. Chromium (Cr) was the metal mostly accumulated and Lead $(\mathrm{Pb})$ was the least accumulated metal.

\section{Bioaccumulation of Binary Mixture of Heavy Metals by Clarias Gariepinus Exposed to Sublethal Concentrations}

The concentration of binary combination of $\mathrm{Cd}: \mathrm{Pb}, \mathrm{Cd}$ : $\mathrm{Cr}$ and $\mathrm{Cr}$ : $\mathrm{Pb}$ is presented in Table 9. 


\section{International Journal of Oceanography \& Aquaculture}

\begin{tabular}{|c|c|c|c|c|c|c|}
\hline Days & \multicolumn{2}{|c|}{ Cd:Pb } & \multicolumn{2}{c|}{ Cd:Cr } & \multicolumn{2}{c|}{ Cr:Pb } \\
\hline & $1 / 10^{\text {th }}$ & $1 / 100^{\text {th }}$ & $1 / 10^{\text {th }}$ & $1 / 100^{\text {th }}$ & $1 / 10^{\text {th }}$ & $1 / 100^{\text {th }}$ \\
\hline 0 & ND & ND & ND & ND & ND & ND \\
\hline \multirow{2}{*}{7} & $1.811+0.001:$ & $0.210+0.001:$ & $2.331+0.001:$ & $0.271+0.001:$ & $29.191+0.001:$ & $3.014+0.001:$ \\
& $0.029+0.001$ & $0.002+0.001$ & $80.142+0.001$ & $8.560+0.001$ & $0.031+0.001$ & $0.002+0.001$ \\
\hline \multirow{2}{*}{14} & $1.873+0.001:$ & $0.244 \pm 0.001:$ & $2.416+0.001:$ & $0.279+0.001:$ & $30.013+0.001:$ & $3.318+0.001:$ \\
& $0.032+0.001$ & $0.002+0.001$ & $88.024+0.001$ & $9.112+0.001$ & $0.041+0.001$ & $0.003+0.001$ \\
\hline \multirow{2}{*}{21} & $1.980+0.001:$ & $0.283+0.001:$ & $2.782+0.001:$ & $0.289+0.001:$ & $30.834+0.001:$ & $3.477+0.001:$ \\
& $0.038+0.001$ & $0.003+0.001$ & $97.371+0.001$ & $9.976+0.001$ & $0.044+0.001$ & $0.003+0.001$ \\
\hline \multirow{2}{*}{28} & $2.325+0.001:$ & $0.301+0.001:$ & $2.814+0.001:$ & $0.293+0.001:$ & $32.181+0.001:$ & $3.492+0.001:$ \\
& $0.038+0.001$ & $0.003+0.001$ & $105.306+0.001$ & $10.423+0.001$ & $0.047+0.001$ & $0.004+0.001$ \\
\hline
\end{tabular}

Table 9: Bioaccumulation Concentrations of $\mathrm{Cd}: \mathrm{Pb}, \mathrm{Cd}: \mathrm{Cr}$ and $\mathrm{Cr}: \mathrm{Pb}$ in Clarias gariepinus ( $\mu \mathrm{g} / \mathrm{g}$ ).

There was observed time-dose response relationship in the data sets in increasing direction with respect to the concentration of the metals in the exposed fish. Chromium (Cr) was also observed to be the metal with the highest concentration and Lead $(\mathrm{Pb})$ the metal with the least concentration in the test animals.

\section{Bioaccumulation of Equitoxic Multiple Mixtures of Heavy Metals (Cd: Cr: Pb)}

The triple mixture of $\mathrm{Cd}: \mathrm{Cr}: \mathrm{Pb}$ concentrations are shown in Table 10.

\begin{tabular}{|c|c|c|}
\hline Days & \multicolumn{2}{|c|}{ Cd:Cr:Pb } \\
\hline & $1 / 10^{\text {th }}$ & $1 / 100^{\text {th }}$ \\
\hline 0 & $\mathrm{ND}$ & $\mathrm{ND}$ \\
\hline 7 & $0.712+0.001: 14.124+0.001: 0.011+0.001$ & $0.053+0.001: 1.285+0.001: 0.001+0.001$ \\
\hline 14 & $0.719+0.001: 16.076+0.001: 0.018+0.001$ & $0.067+0.001: 1.291+0.001: 0.001+0.001$ \\
\hline 21 & $0.734+0.001: 16.537+0.001: 0.029+0.001$ & $0.069+0.001: 1.376+0.001: 0.001+0.001$ \\
\hline 28 & $0.761+0.001: 16.613+0.001: 0.041+0.001$ & $0.082+0.001: 1.438+0.001: 0.002+0.001$ \\
\hline
\end{tabular}

On the basis of the result, similar trend of dose response relationship was seen dependent on the exposure duration. The test animal bio accumulated chromium more than any other metal.

\section{Discussion}

\section{Acute Toxicity Studies / Bioassay}

Under the single action toxicity test carried out, $\mathrm{Cd}$ was the most toxic to the test animal with the lowest $96-\mathrm{h}$ $\mathrm{LC}_{50}$ of $(8.280 \mathrm{mg} / \mathrm{L})$ (Table 4.7) while lead $(\mathrm{Pb})$ was the least toxic $\left(96-\mathrm{h} \mathrm{LC}_{50}\right.$ value of $\left.70.183 \mathrm{mg} / \mathrm{L}\right)$.The high toxicity of $\mathrm{Cd}$ has been previously demonstrated by several workers against fish species [5,6]. The high toxicity of $\mathrm{Cd}$ could be attributed to its high electropositivity. The low toxicity of $\mathrm{Pb}$ has also been reported widely in the literature. For example, Paul, et al. [7] was unable to establish a $96-\mathrm{h} \mathrm{LC}_{50}$ value for lead acetate $(90.43 \mathrm{mg} / \mathrm{L})$ against Channa punctatus because the compound did not cause any mortality of the exposed animal in their study "Lead toxicity on non-specific immune mechanisms of freshwater fish Channa punctatus".
Certainly, a number of interactions in joint toxic action of pollutants results in synergism in which the toxicity of a pollutant may be enhanced several folds by the presence of another pollutant against organisms. For example, Enajekpo [8] demonstrated that toxicity of spent engine oil against C.africanus was increased by over 2000 folds by the presence of Nuran insecticides in joint action studies.

In the joint action toxicity evaluations with binary and multiple (triple) mixtures carried out on this study, most of the results upon classification with the synergistic ratio agreed mainly with the model of synergism where only a few cases $\mathrm{Cd}$ in $\mathrm{Cd}: \mathrm{Pb}, \mathrm{Cd}$ in $\mathrm{Cd}: \mathrm{Cr}$ and $\mathrm{Cd}$ in $\mathrm{Cd}: \mathrm{Pb}: \mathrm{Cr}$ interactions remained consistent with the model of antagonism. Liu, et al. [9] reported that the mechanism responsible for antagonistic interaction between constituent metal components in a mixture can be attributed to the oxidative stress and competition for uptake/binding sites in the biological interface between the various types of metals. Antagonistic interaction in mixture of pollutants $\mathrm{Cd}: \mathrm{Pb}, \mathrm{Cd}: \mathrm{Cr}$ and $\mathrm{Cd}: \mathrm{Pb}: \mathrm{Cr}$ in this study, where it exists could be an advantage in 


\section{International Journal of Oceanography \& Aquaculture}

environmental management. This is so because antagonism implies that there is interaction between the constituents which result in the lowering of the toxicity of one or all the constituent of mixtures against the living species. Researchers outside the country who have also reported on synergistic interaction between constituent metals of a mixture include Abdullah and King [10] who documented the synergism that occurred in the interactions between $\mathrm{Cu}$ and $\mathrm{Zn}$ against freshwater isopod Asellus aquaticus. The observed synergistic interactions could also have occurred if the metals form complexes, which have greater penetrability with respect to the tissues of the exposed animal than the individual metals when acting alone

On the basis of emerging results obtained from the joint action toxicity studies carried out in this work, it will certainly be more realistic and effective to take into consideration toxicity levels of mixture of pollutants that occurs together in a local ecosystem and not just levels of single action toxicity of individual pollutants in deriving safe limits/standard aimed at protecting organisms in the environment. Although most of the existing safe limit/standards worldwide depended mainly on the existing single action toxicity data, view of such standards in the developed countries consider the results of joint action toxicity measurements against several sensitive species [11].

\section{Bioaccumulation Studies}

The bioaccumulation of $\mathrm{Cd}$ and $\mathrm{Cr}$ in the series of test carried out in this work likely occurred because the experimental animals were able to absorb the metals directly across body surfaces, membranes and ingested food at a faster rate than they were able to metabolize and excrete the absorbed metals. This led to a net gain of the metals in their body tissues. This is in line with the findings of Otitoloju and Don-Pedro $[12,13]$ in their work on bioaccumulation of heavy metals $(\mathrm{Zn}, \mathrm{Pb}, \mathrm{Cu}$ and $\mathrm{Cd}$ ) by Tympanotonus fuscatus exposed to sublethal concentrations of the test metal compounds in laboratory bioassays which recorded higher concentrations of metals that were about 2-6 times higher than the levels accumulated in control animals exposed to 30days period.

Another segment of this work reported here demonstrated the influence of binary and multiple mixtures of metals on the rate and pattern of bioaccumulation in the laboratory bioassays. When Clarias gariepinus were exposed to joint mixtures of $\mathrm{Cd}$ $\mathrm{Pb}, \mathrm{Cd}-\mathrm{Cr}, \mathrm{Cr}-\mathrm{Pb}$ and $\mathrm{Cd}-\mathrm{Cr}-\mathrm{Pb}$, in laboratory bioassays, the concentrations of the metals accumulated by the test animals over 28-day experiments were found to be lower than the concentrations of the respective metals accumulated under the single action studies. This is in accordance with works of Borgmann, et al. [14] which stated that bioaccumulation of metals in mixtures may demonstrate competitive, a, or non-competitive inhibition that may lead to lowered concentrations when compared to single metal bioaccumulation.

\section{Conclusion}

During the single action acute toxicity studies, Cd was the most toxic heavy metal tested against Clarias gariepinus followed by $\mathrm{Cr}$ and $\mathrm{Pb}$ in a decreasing order of toxicity. There were significant departures when the toxicity levels of mixtures (binary and multiple) were compared to the toxicity levels of the individual metals when acting alone against the same test animal. Clarias gariepinus was found to bioaccumulate heavy metals (Cd, $\mathrm{Cr}$ and $\mathrm{Pb}$ ) to varying degrees, dependent on the type of metals, period of exposure, and concentration of metal compound in the test media and the joint action of the metals in the system. Exposure of the test animal Clarias gariepinus to sublethal concentration of the metal mixtures under the joint action studies resulted in a reduction in the concentration of $\mathrm{Cd}, \mathrm{Pb}$, and $\mathrm{Cr}$ accumulated by the test organism, when compared to the concentrations accumulated by the animal during the single action studies.

\section{References}

1. Ansari TM, Marr IL, Tariq N (2004) Heavy Metals in Marine Pollution Perspective-A Mini Review. Journal of Applied Sciences 4(1): 1-20.

2. Mustafa C, Guluzar A (2003) The relationships between heavy metal ( $\mathrm{Cd}, \mathrm{Cr}, \mathrm{Cu}, \mathrm{Fe}, \mathrm{Pb}, \mathrm{Zn}$ ) levels and the size of six Mediterranean fish species. Environmental Pollution 121(1): 129-136.

3. Kingston HM, Jassie LB (1988) Introduction to Microwave Sample Preparation. American Chemical Society. Washington, DC.

4. Don Pedro KN (1989) Mode of action of fixed oils against eggs of Callosobrochus maculates. Pesticide Science 26(2): 107-115.

5. Singh AP, Singh AK, Singh JPN (2007) Cadmium induced changes on the secretion of branchial 


\section{International Journal of Oceanography \& Aquaculture}

mucous cells of peppered loach, Lepdocephalichthys guni. J Exp Zool India 10(1).

6. Kumar P, Singh A (2010) Cadmium toxicity in fish: an overview. GERF Bulletin of Biosciences 1(1): 41-47.

7. Paul N, Chakraborty S, Sengupta M (2014) Lead toxicity on non-specific immune mechanisms of freshwater fish Channa punctatus. Aquatic Toxicology 152: 105-112.

8. Enajekpo HOT (2000) Joint action toxicity of spent lubricant oil (SLO) and insecticides against selected brackish water animals of the Lagos Lagoon. Ph.D Thesis, University of Lagos, pp: 288.

9. Liu X, Chen Q, Ali N, Zhang J, Wang M, et al. (2019) Single and joint oxidative stress-related toxicity of sediment-associated cadmium and lead on Bellamya aeruginosa. Environmental Science and Pollution Research.

10. Abdullah AAM, King PE (2004) Synergistic effects of zinc and copper ions in a freshwater isopod Asellus aquaticus (L). Journal of Basrah Researches 30: 3945.
11. Obiakor MO, Okonkwo JC, Ezeonyejiaku CD, Ezenwelu CO (2010) Genotoxicology: Single and Joint Action of Copper and Zinc to Synodontis clarias and Tilapia nilotica. Journal of Applied Science \& Environmental Management (JASEM) 14(3): 59-64.

12. Otitoloju AA, Don Pedro KN (2002) Bioaccumulation of Heavy metals ( $\mathrm{Zn}, \mathrm{Pb}, \mathrm{Cu}$ and $\mathrm{Cd})$ by Tympanotonus fuscatus var radula (L.) exposed to Sublethal concentrations of the test metal compounds in laboratory bioassays. West African Journal of Applied Ecology 3(1): 17-29.

13. Otitoloju AA (2001) Joint action toxicity of heavy metals and their bioaccumulation by benthic animals in the Lagos lagoon. Ph.D. Thesis, Department of Zoology, University of Lagos, pp: 231.

14. Borgmann U, Norwood WP, Dixon DG (2008) Modelling bioaccumulation and toxicity of metal mixtures. Human and Ecological Risk Assessment 14(2): 266-289. 